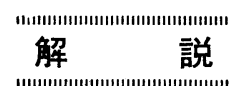

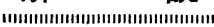

\section{Agrochemistry and Biology Series}

\section{元素からみた生物の世界}

高 橋 英 一

近畿大学農学部植物栄養学研究室

(平成 4 年 8 月 20 日受理)

\title{
How Organisms Have Used Chemical Elements for Their Growth
}

\author{
Eiichi TAKAHASHI \\ Laboratory of Plant Nutrition, Faculty of Agriculture, Kinki University, \\ Nakamachi, Nara 631, Japan
}

\section{元素組成から何がわかるか}

アルファベットを発明した人間は，わずか 26 文字で 莫大な数の言葉をつくりだし (OED には 414,825 語が 収録されている)，それを使ってこの世のあらゆる事象 を記述してきた．同様に化学者はこの地球上に現存する 元素のすべてを知るにいたり，90 足らずの元素記号に よって自然界のあらゆる存在をあらわすことができるよ うになった。これら (生物と無生物) の特徴を手っ取り 早く比較するには，その中に含むれている元素の種類と 量すなわち元素組成が明らかになると便利であるが，最 近の分析技術の進歩はそれを可能にしつつある.ここで は文献ならびに筆者らが行なった分析の結果をもとに， 若干の話題を提供したい。

自然界は無生物之その中で暮らす生物，すなわち大 気, 水, 岩石, '動物, 植物, 微生物から構成されている が，これらに含まれている元素の大部分はマグマの固化 した火成岩から供給される。氺成岩は地表で風化作用を うけて 2 次的に種々の岩石に変じ，これらの岩石を母材 として土壤が生成する，表1にみられるように火成岩と 土壤の元素組成の最も大きなちがいは C と $\mathrm{N}$ の含量で あるが，この二つの元素は生物の光合成と窒素固定の作 用によって大気中の炭酸ガスと窒素ガスからもたらされ たものである．したがって土壌は単なる岩石の風化物で はなく，生物の㗢きによってつくられたものであり，生 物活動の舞台となっている.

代表的な陸上植物である被子植物の $\mathrm{C}$ と N の含量は 土裹よりさらに著しく高くなっているが，土堙の 3 大成 分である $\mathrm{Si}, \mathrm{Al}, \mathrm{Fe}$ の含量は著しく低い. 被子植物に くらべるとその捕食者である哺乳動物は $\mathrm{N}, \mathrm{P}, \mathrm{Ca}$,
$\mathrm{Na}$ が高く，K，Mg，O が低いという特徴がみられる. これは哺乳動物は食物から $\mathrm{P}$ と Caを集めて骨格成分 のアパタイトをつくるためであり，Na 塩を主成分とす る体液を循環させていることの反映である．また炭酸同 化のできない動物の細胞は細胞膜のみで，植物の細胞の ようにセルロースからなる厚い細胞壁をもたず，かわり に細胞と細胞の間はコラーゲンタンパクで埋められてい る. そのため相対的にタンパク質の含量が高くなり，そ れが高い $\mathrm{N}$ 含量と低い $\mathrm{O}$ 含量となってあらわれている (タンパク質の $\mathrm{O}$ 含量はセルロースの約半分である). $\mathrm{K}$ と $\mathrm{Mg}$ における差は, 陸上植物は塩生植物を除き $\mathrm{Na}$ にくらべて K を著しく吸収する性質があり，また葉緑 体をむっているためである.

生物は単細胞生物から多細胞生物一進化してゆくにつ れ，特殊な組織器官を分化させて複雑な機能をもつよう になったが，個体としての元素組成の特徵もその過程で 生じたと思われる. 単細胞生物のバクテリアと哺乳動物 細胞の元素組成はよく似ているが (表 1)，このことは基 本的な代謝の営まれる細胞の実質 (細胞質) の組成は, 生物の種をこえて共通していることを示唆している.

\section{動物と植物における必須元素のちがい}

表 2 に現在までにみとめられている維管束植物と哺 乳動物の必須元素を示した. 両者の微量必須元素の数 は, 1954 年の時点では同数の 7 元素であったが, それ 以後に追加された元素は植物にはないのに対して動物で は9 元素の多きにのぼっている.この両者における必 須元素要求性のちがいは何を示しているのであろらか.

たとえば Na は古くから動物の多量必須元素であるこ とが知られているが，植物においては必須元素になって 
表 1 岩石, 土壌，植物，動物の元素組成の比較

\begin{tabular}{|c|c|c|c|c|c|c|c|c|}
\hline & $\begin{array}{c}\text { 火成岩 } \\
(\%)\end{array}$ & $\begin{array}{l}\text { 土 壌 } \\
(\%)\end{array}$ & $\frac{\text { 土襄 }}{\text { 火成岩 }}$ & $\begin{array}{c}\text { 被子植物 } \\
(\%)\end{array}$ & $\begin{array}{c}\text { 哺乳動物 } \\
(\%) \\
\text { (\%) }\end{array}$ & $\frac{\text { 哺乳動物 }}{\text { 被子植物 }}$ & $\begin{array}{c}\text { バクテリア } \\
(\%)\end{array}$ & $\begin{array}{l}\text { 哺乳動物 } \\
\text { 細胞 } \\
(\%)\end{array}$ \\
\hline $\mathrm{C}$ & 0.02 & 2.00 & 100 & 45.40 & 48.40 & 0.94 & 53.80 & 52 \\
\hline $\mathrm{H}$ & 0.14 & 0.15 & 1 & 5.50 & 6.60 & 1.20 & 7.40 & 9 \\
\hline $\mathrm{O}$ & 46.40 & 49.00 & 1.06 & 41.00 & 18.60 & 0.45 & 23.00 & 22 \\
\hline $\mathrm{N}$ & 0.002 & 0.10 & 50 & 3.00 & 8.70 & 2.90 & 9.60 & 12 \\
\hline $\mathrm{P}$ & 0.11 & 0.07 & 0.64 & 0.23 & 4.30 & 18.70 & 3.00 & 1 \\
\hline $\mathrm{S}$ & 0.03 & 0.07 & 2.33 & 0.34 & 0.54 & 1.59 & 0.53 & 1 \\
\hline $\mathrm{K}$ & 2.09 & 1.40 & 0.67 & 1.40 & 0.54 & 0.39 & (残 2.67) & (残 3) \\
\hline $\mathrm{Na}$ & 2.36 & 0.63 & 0.27 & 0.12 & 0.38 & 3.17 & & \\
\hline $\mathrm{Ca}$ & 4.15 & 1.37 & 0.33 & 1.80 & 8.50 & 4.72 & & \\
\hline $\mathrm{Mg}$ & 2.33 & 0.50 & 0.21 & 0.32 & 0.10 & 0.31 & & \\
\hline $\mathrm{Cl}$ & 0.01 & 0.01 & 1 & 0.20 & 0.32 & 1.60 & & \\
\hline $\mathrm{Si}$ & 28.15 & 33.00 & 1.17 & 0.20 & 0.01 & 0.05 & & \\
\hline $\mathrm{Al}$ & 8.23 & 7.10 & 0.86 & 0.05 & 0.001 & 0.02 & & \\
\hline $\mathrm{Fe}$ & 5.63 & 3.80 & 0.67 & 0.01 & 0.01 & 1 & & \\
\hline
\end{tabular}

H. J. M. Bowen: “Trace Element in Biochemistry,” Academic Press, p. 16, 39, 68, 1966

表 2 植物, 動物の必須元素之発見年代

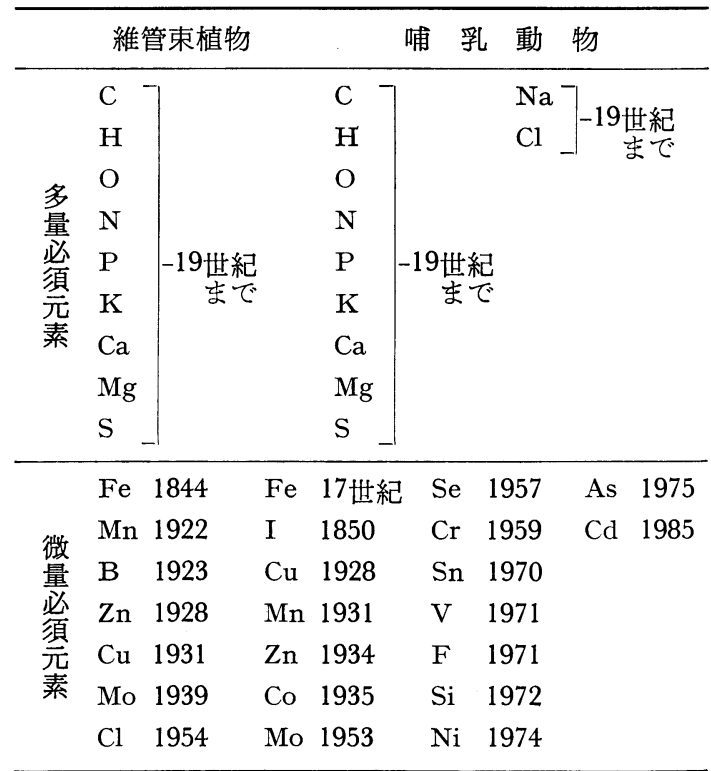

いない，逆に動物ではこれだけ多数の微量必須元素が追 加されたのに，Bはまだ入っていない，また Si は古く からイネ科植物における役割について研究されいるいる な効果がみとめられているが，植物の必須元素にはなっ ていない(ただしケイ藻に対しては必須性がみとめられ ている). ところが動物では最近微量必須元素に加えら れた.さらに $\mathrm{Cl}$ や Moのように同じく必須元素になって いても, 必須性の内容が動物と植物で異なる場合もある.
このように必須元素を一つ一つ点検して, 動物と植物 におけるちがいの意味や，元素がある生物において必須 性を獲得するにいたった過程を考えてみるのは興味深い ことであろう．ここでは必須元素の中， $\mathrm{Na} ＼textrm{S i} ， \mathrm{~B}$ に ついて考察を試みたい。

\section{ナトリウム}

体重 $70 \mathrm{~kg}$ の人の体には約 $85 \mathrm{~g}$ の $\mathrm{Na}$ が含まれてお り，それは細胞外液 (血漿之組織間液) 之骨格にとれぞ れ 45\%, 残りは細胞中に存在しているといわれる.つ まり体の中の $\mathrm{Na}$ の大部分は細胞の外にあるが，これと 対照的なのは $\mathrm{K}$ で大部分が細胞内に分布している。 そ れは細胞膜に $\mathrm{Na} / \mathrm{K}$ ポンプがあり，細胞内の $\mathrm{Na}$ を汲 みだし $\mathrm{K}$ を波み入れるからである。これは植物でも同 じで，表 3 にみられるように海藻でも海水にくらべて $\mathrm{K}$ は著しく濃縮されているが，Naの含量は相対的に抑 えられている.

クロード・ベルナールは細胞外液の存在を内部環境と

表 3 海藻, 牧草の $\mathrm{Na}, \mathrm{K}$ 含量の一例

\begin{tabular}{lcccc}
\hline & 海水 & $\begin{array}{c}\text { 永ルス } \\
\text { (紅藻類) }\end{array}$ & $\begin{array}{c}\text { コンブ } \\
\text { (褐藻類) }\end{array}$ & 牧草 \\
\hline $\mathrm{Na}(\%)$ & 1.05 & 2.07 & $1.35 \sim 2.88$ & 0.13 \\
$\mathrm{~K}(\%)$ & 0.04 & 7.91 & $5.25 \sim 8.15$ & 1.99 \\
$\mathrm{Na} / \mathrm{K}$ & 26 & 0.26 & $0.26 \sim 0.35$ & 0.07 \\
\hline
\end{tabular}

西澤一俊：海藻学入門, 講談社, 東京, p. 160, 1989 
呼び，体の外の外部環境と対応させてその重要性を強調 したが，Na は細胞をとりかこむ内部環境にあって恒常 性を維持するため $\mathrm{pH}$ や浸透圧の調節に，なた細胞膜 通過を介して刺激の伝達やアミノ酸, 糖の取込みに重要 な役割を演じている.

海棲の単細胞生物は養分の吸収と排泄を直接まわりの 海水に対して行なっているが，細胞外液の組成が海水に 似ているところから（細胞外液の $\mathrm{Na} / \mathrm{K}$ モル比は 36 , 海水のそれは 47 である), 陸悽の多細胞動物の体を構 成している個々の細胞も海棲の単細胞動物 (原生動物) に似た環境におかれているといえる、すなわち細胞外液 の流れは個々の細胞に酸素や養分を運び，炭酸ガスや老 廃物をとりのぞく働きをしている．これが循環系で血管 系とリンパ管系とポンプの役割をする心臓からなり，こ れにガス交換をする脯藏，溶質の濾過を行なう腎蔵，養 水分の消化吸収をする胃と腸, 吸収した養分の処理や貯 蔵を行なう肝藏がつけ加わったのがわれわれの体の栄養 器官系である.

これに対して植物には循環系の分化もなければ動物の 細胞外液に相当するものもない. 陸上植物の細胞は動物 の細胞のように“海の衣”をまとっておらず，ここに塩 生植物は除き一般の植物の $\mathrm{Na}$ 含量が動物にくらべて 低く，また動物のような要求性を Naに対してもたない 原因がある.しかし細胞の中味 (細胞質) は，おそらく 最初に細胞が形成されたとき以来, 動物も植物も高 $\mathrm{K}$ 低 $\mathrm{Na}$ の組成を推持してきたと思われる，このようにみ てゆくと，個体としての生物の Naに対する挙動のちが いは, 高度好塩細菌など特殊な生物は別として, 細胞質 の外の部分にあると考えられる.

一般の植物は 1 価のアルカリカチオンである $\mathrm{K}$ と Na のうち $\mathrm{K}$ を選択的に吸収し，その含量は動物にくらべ て著しく高いという特徴がある. それで 19 世紀中頃ド イッでカリ鉱床が発見されるまでの長い間, 人類は植物 を焼いて生じる灰を容器に集め, 水で抽出乾固してカリ 塩を得ていた. カリがポタッシ (pot-ash) とも呼ばれ ているゆえんである.カリは肥料だけでなく，火薬の原 料としてかかせない硝石 $\left(\mathrm{KNO}_{3}\right)$ をつくるのに必要で あったので，それを得るためにヨーロッパやアメリカの 森林は荒廃するにいたった。

植物が動物の要求に応じうるだけの $\mathrm{Na}$ を含んでいな いことの影響は大きい. 草食動物は塩気のあるところを 探しもとめるし，人類にとって塩は重要な交易品であり それは“塩の道”“敵に塩を送る”“サラリー”などの 言葉として残っている.多くの陸上植物は土㐮溶液の $\mathrm{Na}$ 濃度が $0.1 \%$ くいになると生育が阻害される.こ
の濃度は海水の 10 分の 1 にすぎないけれども, 陸上で は蒸散作用によって体内で濃縮がおこるため阻害をひき おこすのである．植物が光合成によって乾物 $1 \mathrm{~g}$ 相当の 生長をする間に，300〜800 g の水が体の中を通過する. これを蒸散係数というが仮りに 500 とすると，ジュー スをストローで吸うように植物が塩水をそのます吸収す れば体内で 500 倍, $0.1 \%$ の $\mathrm{Na}$ は $50 \%$ に濃縮される ことになる．植物は大なり小なり $\mathrm{Na}$ 排除能をもってい るが，もし十分強くなければ $0.1 \%$ 程度でも阻害をう けることは容易に理解できよう。

しかし陸上植物の中には海水に近い $\mathrm{Na}$ 濃度のところ でも生育するものがある．表 4 に一例を示したが,これ らの中ヨシは広塩性植物 (euryhaline plant), 他は塩 生植物 (halophytə) と呼ばれるものである. ヨシは元 来は淡水性であるが，塩分濃度の相当高いところでも生 育は可能である。それはヨシは $\mathrm{Na}$ 排除能が強く，K 吸収力が高いからで，表にみられるように土壤溶液の濃 度が海水より高いところでも，ヨシの $\mathrm{Na}$ 含量は低く $\mathrm{K}$ 含量は高く保たれている. これに対して塩生植物の $\mathrm{Na}$ 含量は著しく高く，K 含量は低めである.このような 植物を集めて焼けば, 灰からソーダをとることができる. Soda の語源はアラビア語の Suwwād という植物に由 来しており, それは塩生植物のマッナ属 Suaeda の学 名になっている. ちなみに表 4 のハママッナの学名は Suaeda maritima である.

これらの塩生植物は吸収した Naを細胞容積の大部分

表 4 塩生, 広塩性植物の $\mathrm{Na}, \mathrm{K}$ 含量と生育地の 塩類濃度

\begin{tabular}{|c|c|c|c|}
\hline & $\begin{array}{c}\mathrm{Na} \\
(\%)\end{array}$ & $\begin{array}{c}\mathrm{K} \\
(\%)\end{array}$ & $\mathrm{Na} / \mathrm{K}$ \\
\hline \multicolumn{4}{|l|}{ 琵琶湖西岸(柳ヶ崎) } \\
\hline 土壃溶液 & 0.001 & 0.01 & 0.1 \\
\hline$\exists \quad シ$ & 0.01 & 1.77 & 0.006 \\
\hline \multicolumn{4}{|l|}{ 千種川河口(赤穂) } \\
\hline 土壤溶液 & 0.75 & 0.05 & 15.0 \\
\hline$\exists \quad シ$ & 0.34 & 2.93 & 0.12 \\
\hline ホソバノハマアカザ & 8.35 & 2.52 & 3.3 \\
\hline ハママツナ & 10.3 & 1.23 & 8.4 \\
\hline \multicolumn{4}{|l|}{ 錦海塩田跡地 (牛空) } \\
\hline 土癏溶液 & 1.55 & 0.08 & 19.4 \\
\hline$\exists \quad シ$ & 0.19 & 2.53 & 0.08 \\
\hline ウシオツメクサ & 5.65 & 1.47 & 3.8 \\
\hline アツケシソウ & 17.6 & 1.01 & 17.4 \\
\hline
\end{tabular}

参考図書 2), p. 99 
を占める大きな液胞の中に集積し，細胞質から隔離する とともに浸透圧を発生して, 外界の塩類濃度の高い溶液 から水分を吸収することを可能にし，高い膨圧を維持す るのに役立てている(そのために葉は多肉化する).この ようなことが可能なのは，液胞膜に Na を細胞質から液 胞中へ波みだすポンプがあるからである.

塩類を集積する塩生植物は耐塩性が強いだけでなく， 塩類濃度がある程度高いときのほうが生育がよい。たと えばホソバノ八マアカザの生育は $50 \mathrm{~mm}$ (海水の 10 分 の 1，一般の植物が生育阻害をうける濃度) のナトリウ 厶塩のとき最高になる．カリウム塩でも同程度の効果が あるので，ホソバノ八マアカザは 1 価カチオンの要求量 が高く,海水の影響をうけているところではそれにNaを 利用している. しか乙海水の 2 分の 1 程度の高濃度になる そ，ナトリウム塩では生育可能だがカリウム塩の場合は 枯死してしまう。 ホソバノ八マアカザは自生地の高 $\mathrm{Na}$ 条件にはよく適応しており，生育をそこなうほどNaを 吸収しないように自己調節できるが，高 $\mathrm{K}$ 条件には適応 できていないためにこのようなことがおこるのである.

このほかマングローブと総称されている樹種にも耐塩 性の強いものがあるが，これらの中には葉に塩腺をもち 樍極的かつ選択的に Naを排泄し，一定以上に濃度が高 まらないようにしているものがある．面白いことに動物 にもこれと似た器官をもつものがある．海棲の爬虫類や 海鳥には，食物とともに飲みこんだ海水中の $\mathrm{NaCl}$ を海 水より濃い溶液で排出する塩腺が, 眼窩 (ウミガメ，イ グアナ) や鼻腔 (海鳥) に開口している.

海に誕生した生物は，Naに対しては常に細胞の外 (液胞内も細胞の外である) に隔離しながら利用すると いう仕方で進化してきたことがうかがわれる。なお最近 $\mathrm{C}_{4}$ 型植物の中に少量の $\mathrm{Na}$ が必須らしい状況証拠が得 られているが，そのしくみの詳細はまだ明らかになって いない.

\section{ケ イ 素}

$\mathrm{Si}$ は自然界では $\mathrm{P}$ と同じように $\mathrm{O}$ とむすびついて， ケイ酸 $\left(\mathrm{SiO}_{2}\right)$ またはその塩として存在する. $\mathrm{Si}$ と $\mathrm{O}$ はそれぞれクラーク数第 2 位と第 1 位の元素であり,こ の二つの連合であるケイ酸は地款の半ば以上を占めてい る. しかし溶解度は低いため, 溶存ヶイ酸の濃度は数 $\mathrm{ppm}$ ないし数十 $\mathrm{ppm}$ の範囲である.ところで生物は 体を保護するための硬組織をもっているが，生物のある ものはその材料にケイ酸を使っている．硬組織の素材に はセルロース，リグニンやキチン，コラーゲンなどの有 機系のものと, ケイ酸, 炭酸カルシウム, リン酸カルシ
ウムなどの無機系のものがあるが，そのいずれをえらぶ かによって生物の特徽がみとめられる，植物の硬組織 (細胞壁，木化細胞）は主としてセルロース，リグニンか らなり，カルシウムやケイ酸はその補強的役割をしてい るにすぎないが，動物では無機系のものの占める割合が 大きい,

表 5 に動物の硬組織の元素組成を示したが，原生動 物，海綿動物ではケイ酸型と炭酸カルシウム型が共存し ているが，腔腸動物以上になると炭酸カルシウム型のも ののみとなり，さらに哺乳動物ではリン酸カルシウム型 になっている．動物はこのほかに有機質も硬組織の素材 にしており，海綿動物の中の棌浴海綿は硬タンパク質の マトリックスの海綿質のみからなっている。このように 動物の硬組織形成に関与する有機質のマトリックス生 成，ケイ質化，石灰化の三つのプロセスには生物進化と の関係がうかがわれるが，さらに興味深いことに，同じ 動物の一生の間にこれらのプロセスがつぎつぎにおこる もののあることが知られている。すなわち Sclerospongiae 属のある海綿では，はじめヶイ酸質の骨格ができ，

表 5 生物の硬組織の $\mathrm{Si}, \mathrm{Ca}$ 含量 ${ }^{5)}$

\begin{tabular}{|c|c|c|c|}
\hline & $\begin{array}{c}\mathrm{Si} \\
(\mathrm{ppm})\end{array}$ & $\begin{array}{c}\mathrm{Ca} \\
(\mathrm{ppm})\end{array}$ & $\mathrm{Si} / \mathrm{Ca}$ \\
\hline \multicolumn{4}{|l|}{ 原生動物 } \\
\hline ケイ酸型(有孔虫) & 410,000 & 17,000 & 24.1 \\
\hline $\begin{aligned} & \text { 炭酸カルシウ } \text { 型 } \\
& \text { (有孔虫) }\end{aligned}$ & 12,000 & 355,000 & 0.03 \\
\hline \multicolumn{4}{|l|}{ 海綿動物 } \\
\hline ケイ酸型(ガラス海綿) & 430,000 & 17,000 & 25.7 \\
\hline $\begin{array}{r}\text { 炭酸カルシウ 公型 } \\
\text { (石灰海綿) }\end{array}$ & $\cdots$ & 341,000 & $\cdots$ \\
\hline \multicolumn{4}{|l|}{ 腔腸動物 } \\
\hline 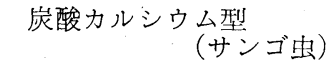 & 1,000 & 365,000 & 0.003 \\
\hline \multicolumn{4}{|l|}{ 棘皮動物 } \\
\hline 炭酸カルシウム型 (ウ二) & 4,000 & 352,000 & 0.01 \\
\hline \multicolumn{4}{|l|}{ 軟体動物 } \\
\hline 炭酸カルシウム型(貝) & 800 & 395,000 & 0.002 \\
\hline \multicolumn{4}{|l|}{ 甫乳動物 } \\
\hline リン酸カルシウム型 & 100 & 257,000 & 0.0004 \\
\hline (ヒト) & $\begin{array}{r}118,000 \\
45,000\end{array}$ & F 1,5007 & \\
\hline
\end{tabular}

藻類

$\begin{array}{lrrc}\text { ケイ酸型(ケイ藻) a } & 200,000 & 8,000 & 25.0 \\ \text { 炭酸カルシウム型(紅藻) } & 1,000 & 300,000 & 0.003\end{array}$

a) 全生物体の分析値.

参考図書 3), p. 153 
ついでこれが部分的に有機質のマトリックスに包まれ， 最後に石灰質の骨格の中に埋なるという．さらにヶイ酸 は 1970 年代になってヒヨコの成長や骨格形成に微量必 要であることが証明され，哺乳動物の必須元素の表に加 えられたが，その研究でケイ酸は骨形成の初期の段階で 重要な役割をもっていることが明らかにされた.

植物の場合もケイ酸型とカルシウム型の二つの系統の あることがみとめられる，藻類では，石灰藻とも呼ばれ る紅藻は炭酸カルシウムを集積し，一方ケイ藻はケイ酸 を集積する(表 5). ケイ藻においてはケイ酸は乾物の $40 \%$ 以上を占めており，細胞壁の外側に独特の紋様を もった殼を形成するが，無ケイ酸培地でケイ藻を培養す ると分裂増殖が停止することから必須元素になってい る. 陸上植物にも表 6 にみられるように $\mathrm{Si}$ 含量の高い ものがあり，それらはをた $\mathrm{Ca}$ と B 含量が低い傾向が みられる. この三つの特徴を指標にして, 約 600 種の 植物の分析結果からケイ酸型の分布をみたところ，ケイ 酸植物は陸上植物の系統樹の上で科なたは亜科レベルで まとまって存在していた。

植物のケイ酸含量の種間差異の原因は植物のケイ酸吸 収力にある. 植物を水耕し，水耕液の養分濃度の変化を しらべると養分の吸収速度がわかる，植物は多量の水を 吸収蒸散しているが，ある養分の吸収が水よりおそいと きは時間の経過とともに水耕液中の濃度は高くなり，同

表 6 同一土壤に栽培された 175 種類の植物地上部 の $\mathrm{Si}, \mathrm{Ca}, \mathrm{B}, \mathrm{K}$ 含量 $^{3)}$

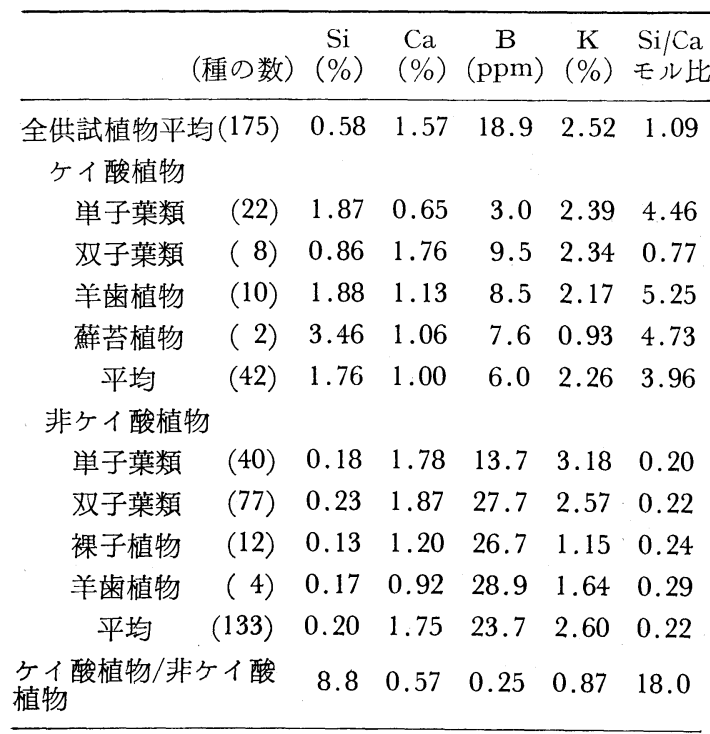

参考図書 3), p. 166
じ速さのときは濃度はかわらず，水より速いときは濃度 は低下する．この方法で植物のケイ酸吸収性を比較する と三つの型, すなわち能動型，受動型，排除型のあるこ とがわかった。能動型（イネ，トクサなど）は典型的な ケイ酸集積植物であり，ケイ酸の吸収は好気呼吸にリン クして行なわれる，受動型（キウリなど）では水耕液の ケイ酸濃度が高いときケイ酸含量はかなり高くなるが, $\mathrm{Ca}$ 含量はそれよりも高い. 排除型は根のまわりでケイ 酸が濾され, 地上部のケイ酸含量は低い. 植物のケイ酸 含量の著しいちがいの原因が根部にあることは，根を切 除するとケイ酸吸収性はすべて受動型になることからも わかる。

$\mathrm{Si}$ の同族元素に Ge があるが, 植物はゲルマニウム酸 $\left(\mathrm{H}_{4} \mathrm{GeO}_{4}\right)$ の吸収に際してケイ酸 $\left(\mathrm{H}_{4} \mathrm{SiO}_{4}\right)$ の場合と 同じ挙動をし，両者を区別できない。これは植物の選択 吸収のしくみを考える上で興味深い現象である.

典型的なケイ酸植物であるイネは十分にケイ酸を吸収 でさるときは 15〜20\%の高含量を示すが，このイネ を無ケイ酸で水耕栽培すると生育および穀実収量は著し く低下する. その原因は蒸散量の増加や葉身下垂の現象 から葉身内に水分ストレスが生じ， $\mathrm{CO}_{2}$ の同化が抑制さ れることにあるのではないかと思われる. 野外の直場に おいても，土堙の可給態ケイ酸レベルが低いところでは 葉身が弯曲気味の草型となり，相互遮へいを助長して群 落の光合成効率を低下させることが指摘されている，さ らに野外ではケイ酸含量の低いイネは病虫害や倒伏の被 害をうけやすく，これは窒素を多用するほど助長される ことが知られている. 日本には可給態ケイ酸の低い水田 がかなり分布しており，また単収を上げるために密植多 肥栽培が行なわれていることもあって，ケイ酸塩の効果 がみられる場合が多い，そのため日本ではケイ酸肥料之 いう世界に例をみない肥料がはじめてつくられた。

ケイ酸は作物だけでなく野生植物にも有効な場合があ る. サバンナはイネ科植物が密生する草原であるが，こ れらの植物はケイ酸を吸収集積することによって乾燥に 耐古，捕食者から身を守るのに役立てているといわれ る.植物に吸収された水溶性ケイ酸は濃縮されると自然 にゲル化し，表皮組織の細胞壁に沈積する．このような 性質があるため，ケイ酸は Naのように過剩障害をおこ すことはなく，植物は体の外側を沈積したケイ酸でカバ 一して，水分の損失やカビなどの侵入を防ぐのに利用で きる.

ケイ酸とのかかわり方は動物も植物も本質的には同じ である、いずれもとり入れたケイ酸を力学的素材として 利用し，そのぶん有機炭素を節約している. 


\section{ホウ素}

B は先に述べたように動物に対しては必須性が認め られていない. しかし植物でも必須性が確認されている のは羊歯植物以上すなわち維管束植物であり，藻類や蘚 苔類に対しては明らかではない. B は $\mathrm{Si}$ と同じく と結びついてホウ酸 $\left(\mathrm{H}_{3} \mathrm{BO}_{3}\right)$ またはその塩として存在 するが，このホウ酸はシスの水酸基をもつ有機化合物と 結合するという特性をもっている．生体内にはこのよう な化合物は少なくないので，体内にとりこまれたホウ酸 がいろいろな生理作用を呈するであろうことは想像にか たくない，現在動物に関するホウ酸の知見は毒作用のみ であるが (ホウ酸入り煎餅などの食品中毒, 病院でのホ ウ酸水の生理的食塩水との誤用など), ホウ酸のこのよう な作用は洗眼薬や不易糊 (ホウ酸入りデンプン糊)やゴ キブリ退治 (ホウ酸団子) などに利用されている.

作物においても必須性 (欠乏) と毒性 (過剩) の二つ の問題がある. 植物の $\mathrm{B}$ 含量は，表 7 にみられるよう に種類によって大きく異なるが，これは植物の B 要求 性，B 耐性の差異とも関係している. この B 含量の差 異は膜壁の性質に原因しているらしいことが，表の植物

表 7 作物のホウ素含量, 要求性, 吸着容量

\begin{tabular}{|c|c|c|c|c|c|}
\hline 作物の種類 & 分类 & 貝上の位置 & $\begin{array}{l}\text { B 含量 } \\
\text { 地上部 } \\
\text { 乾物 } \\
(\mathrm{ppm})\end{array}$ & $\begin{array}{l}B \text { 要求 } \\
\text { 性 }^{a)}\end{array}$ & $\begin{array}{l}\text { B 吸着 } \\
\text { 容量 } \\
(\mu \mathrm{g} / \mathrm{g} \\
\text { 乾根 })\end{array}$ \\
\hline オオムギ & \multirow{4}{*}{$\begin{array}{l}\text { 単 } \\
\text { 葉 } \\
\text { 類 }\end{array}$} & イネ科 & 2.3 & \multirow{4}{*}{ 小 } & 3 \\
\hline ライムギ & & " & 3.1 & & 4 \\
\hline コムギ & & " & 3.3 & & 5 \\
\hline トウモロコシ & & " & 5.0 & & 4 \\
\hline ホウレンソウ & \multirow{5}{*}{$\begin{array}{l}\text { 双 } \\
\text { 葉 } \\
\text { 類 } \\
\end{array}$} & アカザ科 & 10.4 & \multirow{5}{*}{ 中 } & \multirow{5}{*}{11} \\
\hline キクチシャ & & キク科 & 13.1 & & \\
\hline エンドウ & & マメ科 & 21.7 & & \\
\hline ニンジン & & セリ科 & 25.0 & & \\
\hline タバコ & & ナス 科 & 25.0 & & \\
\hline キャベツ & \multirow{7}{*}{$\begin{array}{l}\text { 叒 } \\
\text { 葉! } \\
\text { 類 }\end{array}$} & アブラナ科 & 37.1 & \multirow{7}{*}{ 大 } & \multirow{7}{*}{19} \\
\hline カブラ & & " & 49.2 & & \\
\hline クロカラシナ & & " & 53.3 & & \\
\hline ハッカダイコン & & " & 64.5 & & \\
\hline サトウダイコン & & アカザ科 & 75.6 & & \\
\hline ヒマワリ & & キク 科 & 80.0 & & \\
\hline ケシ & & ケ シ 科 & 94.7 & & \\
\hline
\end{tabular}

a) K. C. Berger: Adv. Agron. 1, 355 (1949)

b) H. Tanaka: Plant Soil 27, 300 (1967)
根の B 吸着容量の大小から推察される.

野外における作物の B 欠乏症にはいろいろなものが 知られている. ビートの heart rot, ダイコン, カブラ の brown heart, ピーナッツの hollow heart, リンゴ の internal cork, セルリー, ミッバの cracking, チュー リップの首折れ，ナタネの不稔等多岐にわたっている. そのためホウ素施肥 (ホウ砂溶液の葉面散布, ホウ酸塩 を添加焀成したリン酸肥料の施用など）が行なわれる.

$\mathrm{B}$ 久乏症の特徴は生長点の細胞や花粉管の破裂, 肥大 根内部の組織細胞の壊死, 表皮細胞組織のひびわれなど にみられるように，細胞膜壁部分の障害となって現われ ることである.このように B 欠乏の症状は顕著である が，B の生理作用は必須元素の中でもっともわかってい ない. ホウ酸イオンはフェノール類と複合体をつくる能 力があることから，維管束植物のフェノール代謝への関 与に注目し，これによって B 欠乏の諸現象を統一的に 説明しようという試みもあるが，仮説の域を脱していな w.

$\mathrm{B}$ の生理作用の研究の進展をはばんでいる原因の一 つに，その微量定量のむつかしいことがある．Bには利 用可能な放射性同位元素がなく，放射化分析もできない. Bは熱中性子吸収能が大きい特性があるためであるが， この性質は原子炉の運転制御棒やガンの放射線治療に利 用されている.このように B は独特の化学性, 生物性 をもっており，もっと興味がもたれてよい元素である.

\section{おわりに}

生物との関係が深いいわゆる“生元素”には, C, H, O, $\mathrm{N}, \mathrm{P}, \mathrm{K}$ などのように細胞の内部にあって機能し，その はたらきはすべての生物に共通している元素と，ここで とりあげた元素のように，細胞の周縁で特殊な役割を果 たしている元素がある. そしてこの後者に属する元素の “生物性”をしらべることは，生物の進化，多様化を考 える上に有益であると思われるのである。

\section{参考図}

1)槀橋英一：動物と植物はどこがちがうか，研成社， 東京, 1989

2）高橋英一：生命にとって塩とは何か，農文協，東 京, 1987

3）香橋英一：ケイ酸植物之石灰植物, 農文協, 東京, 1987

4) 留橋英一： ホウ素之生物一比較栄養論, [16] [17] 〔18〕，農業および園芸 60，1317，1443，1555 (1985) 